\title{
EFFECT OF SALT AND STORAGE TIME ON PHYSICO-CHEMICAL AND SENSORIAL PROPERTIES OF BEEF MEATBALL
}

\author{
R. S. Tanny ${ }^{1}$, M. A. Hashem ${ }^{1}$, S. Akhter, M. S. Islam ${ }^{1}$, M. A. K. Azad ${ }^{1}$, M. S. Ali2 \\ and M. M. Hossain ${ }^{1}$ \\ Department of Animal Science, Bangladesh Agricultural University \\ Mymensigh-2202, Bangladesh
}

\begin{abstract}
The experiment was conducted to find out the effect of salt and storage temperature on the physico-chemical properties of meatball. For this purpose meatball samples were divided into two parts; one is called fresh meatball and another is preserved meatball at different temperatures. Then the fresh samples as well as the preserved samples were divided into four subdivisions. Then these are treated with different salt levels $(0,1.5,3$ and $5 \%$ salt level).These Samples were stored at $4^{\circ} \mathrm{C}$ and $-20^{\circ} \mathrm{C}$ temperature. Samples preserved at $4^{\circ} \mathrm{C}$ were stored in the refrigerator for 21 days and were analyzed on $7^{\text {th }}$ day, $14^{\text {th }}$ day and $21^{\text {st }}$ day and samples preserved at $-20^{\circ} \mathrm{C}$ were stored in the refrigerator for 60 days and were analyzed on $15^{\text {th }}$ day, $30^{\text {th }}$ day, $45^{\text {th }}$ day and $60^{\text {th }}$ day. Dry matter content of all the samples increased with the advancement of storage time, temperature and salt concentration. Ash value decreased with the increase of storage time. Fat value of all the samples decreased with the advancement of salt concentration, storage time and temperature. $\mathrm{pH}$ value of all the samples decreased with the increasing of salt concentration, storage time and temperature. Cooking loss of all the samples increased with increasing of salt concentration but decreased with increasing of storage time and temperature. Dry matter in fresh sample were less than in preserved samples. CP \% of fresh beef meatball was 22.31, 20.55, 14.55 and 20.13 at different salt concentration. The values of CP, DM, Ash and Fat also varied among the samples significantly $(P<0.01)$. Beef meatball can be refrigerated for 60 days in different techniques with more or less difference in the quality. Highly significant differences are observed in preserved samples than in fresh samples at different salt levels. Fresh beef meatball treated with $1.5 \%$ salt found to be more acceptable in terms of sensory evaluation.
\end{abstract}

Key Words: Beef meatball, Salt, Forzen meatball, Refrizerated meatball

\section{INTRODUCTION}

Bangladesh is mainly an agricultural country. She is adorned with different agricultural and livestock product. In our country lion share of the people are directly or indirectly

\footnotetext{
1Professor, Department of Animal Science, Bangladesh Agricultural University, Mymensigh-2202, Bangladesh

2Department of Poultry Science, Bangladesh Agricultural University, Mymensigh-2202, Bangladesh

*Corresponding author (Email: hashem_mdabul@yahoo.com)
} 
concerned with livestock rearing. Livestock in Bangladesh comprise 22.98 million cattle, 1.13 million Buffaloes, 22.40 million goats and 2.88 million sheep contributes in GDP 2.73 percent (DLS, 2009; BER, 2009). Most of the farmers are interested in rearing cattle mainly for meat purpose. Meat is recognized as a highly nutritious food, being an excellent source of high quality protein. Meat is essential to build a healthy nation by providing energy, health and vigor. Various types of meat products are prepared from meat. Among the different meat products meatball is one of the tasty and popular food. Meatballs can be made with beef, lamb, veal, pork, turkey, chicken and even offal. Meatball is a small ball of chopped or ground meat often mixed with bread crumbs and spices. Meatball is processed comminuted meat which can be classified as restructured meat and is very popular among some countries within the Asian region and certain European countries. Meatball is one kind of ready-to-eat food product which is gaining popularity day by day especially for consumer preferences. Unlike olden days where man used to have his food lavishly and slowly, the present trend changed the habits of foods, which are simple and easy to digest. Hence, the existence of these foods fulfilled all the needs of modern human being. Minced meat is used for the preparation of a variety of products such as patties, sausages and meat balls. The minced meat is mixed with various condiments and spices, shaped and then fried or roasted (Hsu et al., 1999). Grinding of meat disrupts the integrity of muscle membranes and exposes lipid membranes to metal ions and facilitates the inter action of pro-oxidants with unsaturated fatty acids resulting in generation of free radicals and propagation of oxidative reaction (Asghar et al., 1988). Salt is a vital ingredient in processed meat as it has numerous technological benefits such as preservation, taste enhancement and water binding. (Durack et al., 2008). Salt is able to increase the water holding capacity of a meat product by extracting myofibrillar proteins which associate into a gel when heated (Foegeding et al., 1987 and Chantrapornchai et al., 2002). However, it is still important to obtain an acceptable limit at which salt can be reduced from processed meat products without negatively impacting functionality, product quality or adversely affect sensorial acceptability, so as to enhance the health status of processed meats. Research work carried out by Tobin et al., $(2012 a, b)$ have shown that salt content can be successfully reduced in processed meat products such as burgers and frankfurters.

The aim of preservation is not only to retard the food spoilage but also to control undesirable changes of wholesomeness, nutritive value and growth of microorganisms (Fennema, 1975). Freezing is the only known method by which meatball can be preserved in a condition similar to their normal state. Freezing at different temperature affect the meatball quality.

The present research work was conducted with a view to identify the acceptable salt level of meatball, the quality of meatball and to find the effect of preservation temperature on the chemical composition of meatball.

\section{MATERIALS AND METHODS}

\section{Collection of meat}

Fresh samples were collected from cattle slaughtered in Sheep and Goat Farm, Department of Animal Science, Bangladesh Agricultural University, Mymensingh. Chemical analysis 
was carried out in the Animal Science Laboratory, Department of Animal Science, BAU, Mymensingh.

\section{Sample preparation}

All visible fat and connective tissue were trimmed off as far as possible with the help of knife and the sample was cut into small pieces. Beef was grinded with the help of meat grinder, then mixed with some spices i.e. garlic paste, Onion paste, chili powder, turmeric powder etc. The meat was aliquot into 4 parts. Each part was mixed with salt at $0 \%, 1.5 \%$, $3 \%, 5 \%$, respectively according to weight basis. Meat from each mixture was taken and wrapped with small square pieces of plastic as a casing. Both end of bag were tied with thread for not entering water and were then placed in to boiling water for cooking. These procedure were made for three times to prepare sample to analyze the first one as fresh basis and the other two were kept in two different freezes at $4{ }^{\circ} \mathrm{C}$ and $-20^{\circ} \mathrm{C}$, respectively for further analysis in various days interval of preservation; it was named the refrigerated meatball. The second portion (freezing temperature $-20^{\circ} \mathrm{C}$ ) of the sausage was named the frozen meatball. Then the samples were packaged in polyethylene bags separately and was kept into the freeze.

\section{Defrosting process}

After storing 7, 14 and 21 and for 15, 30, 45 and 60 days, the samples were defrosted by air, water and microwave oven to prepare for chemical analysis.

\section{Proximate composition}

Proximate composition such as Dry Matter (DM), Ether Extract (EE), Crude Protein (CP) and Ash were measured according to the methods (AOAC, 1995). All determination was done in triplicate and the mean value was reported.

\section{pH measurement}

$\mathrm{pH}$ value of meat was measured using $\mathrm{pH}$ meter from meat homogenate. The homogenate was prepared by blending $2 \mathrm{~g}$ of meat with $10 \mathrm{ml}$ distilled water.

\section{Statistical analysis}

Data were analyzed statistically using the analysis of variance technique in a computer using SAS statistical computer package programmed in accordance with the principle of Completely Randomized Design (CRD). Duncan's Multiple Range Test was done to compare variations between treatments where ANOVA showed significant differences.

\section{RESULTS AND DISCUSSION}

\section{Proximate Composition}

\section{Dry matter}

Dry matter content of meatball at different salt concentration, storage temperature and days are presented in Table 1. Dry matter of fresh meatball of $0 \%$ salt was $31.57 \%$, refrigerated meatball and frozen meatball of $0 \%$ salt at 21 days and 60 days were $33.59 \%$ and $32.54 \%$, 
respectively. Dry matter of fresh meatball of $1.5 \%$ salt was $31.46 \%$ and refrigerated and frozen meatball of $1.5 \%$ salt at 21 and 60 days were $33.57 \%$ and $34.25 \%$, respectively. Dry matter content of fresh meatball of $3.0 \%$ salt was $31.65 \%$ and refrigerated and frozen meatball of $3.0 \%$ salt at 21 and 60 days were $33.43 \%$ and $33.76 \%$, respectively. Dry matter of fresh meatball of $5.0 \%$ salt was $31.84 \%$ and refrigerated and frozen meatball of $5.0 \%$ salt at 21 and 60 days were $33.44 \%$ and $33.83 \%$, respectively. There were little changes of dry matter content during storage time. Dry matter content increased with the increase of storage time and salt concentration in all samples. The loss of moisture probably associated to increased dry matter. The same trend was also observed by Konieczny et al. (2007) and they reported that dry matter content increased during frozen storage. Dry matter increased due to loss of moisture of beef meatball with advance of storage time during freezing. This result is completely consisted with the findings of Huda et al. (2010) where the authors found that the Malayasian commercial beef meatball contains $33.48 \%$ dry matter.

\section{Ash}

Ash was also analyzed up to the end of the storage period of 60 days and the results are presented in Table 1 . Ash of fresh meatball of $0 \%$ salt was $1.14 \%$, refrigerated and frozen meatball of $0 \%$ salt at 21 days and 60 days were $1.03 \%$ and $1.14 \%$, respectively. Ash of fresh meatball of $1.5 \%$ salt was $1.16 \%$ and refrigerated and frozen meatball of $1.5 \%$ salt at 21 and 60 days were $1.04 \%$ and $1.13 \%$, respectively. Ash of fresh meatball of 3.0\% salt was $1.18 \%$ and refrigerated and frozen meatball of $3.0 \%$ salt at 21 and 60 days were $1.07 \%$ and $1.11 \%$, respectively. Ash of fresh meatball of $5.0 \%$ salt was $1.17 \%$ and refrigerated and frozen meatball of $5.0 \%$ salt at 21 and 60 days were $1.04 \%$ and $1.07 \%$, respectively. Ash is decreased with the increase of storage time. Ash value increased with advancement of salt concentration in case of refrigerated temperature but decreased with advancement of salt concentration in case of frozen temperature. This result is fully agreed with the findings of Huda et al. (2010) where the authors found that the Malayasian commercial beef meatball contains $1.76 \%$ ash.

\section{Crude protein}

Crude protein $(\mathrm{CP})$ content was also determined at the end of the storage period of 60 days and the results are presented in Table 1 . CP of fresh meatball of $0 \%$ salt was $22.31 \%$, refrigerated sausage and frozen meatball of $0 \%$ salt at 21 days and 60 days were $21.44 \%$ and $23.08 \%$, respectively. CP of fresh meatball of $1.5 \%$ salt was $20.55 \%$ and refrigerated and frozen meatball of $1.5 \%$ salt at 21 and 60 days were $20.47 \%$ and $21.53 \%$, respectively. CP of fresh meatball of $3.0 \%$ salt was $14.55 \%$ and refrigerated and frozen meatball of $3.0 \%$ salt at 21 and 60 days were $20.45 \%$ and $21.48 \%$, respectively. CP of fresh meatball of $5.0 \%$ salt was $20.13 \%$ and refrigerated and frozen meatball of $5.0 \%$ salts at 21 and 60 days were $20.37 \%$ and $21.37 \%$, respectively. The $\mathrm{CP}$ content decreased due to loss of protein during storage might be related with loss of sarcoplasmic protein, osmosis and poor water holding capacity up to 45 days of storage time and then increased in 60 days of storage period. CP content decreased with increasing salt concentration in case of refrigerated sample. In case of frozen samples, CP content increased with advancement of salt concentration up to 45 days of storage period and then decreased in 60 days. This result is not matched with the findings 
of Huda et al. (2010) where the authors found that the Malayasian commercial beef meatball ranged from $9.22 \%-12.51 \% \mathrm{CP}$.

\section{Fat}

Fat content of samples was also analyzed up to the end of the storage period of 60 days and the results are presented in Table 1 . Fat of fresh meatball of $0 \%$ salt sample was $8.90 \%$, refrigerated sausage and frozen meatball of $0 \%$ salt sample at 21 days and 60 days were $8.80 \%$ and $8.43 \%$, respectively. Fat of fresh meatball of $1.5 \%$ salt sample was $8.58 \%$ and refrigerated and frozen meatball of $1.5 \%$ salt sample at 21 and 60 days were $8.51 \%$ and $8.27 \%$, respectively. Fat of fresh meatball of $3.0 \%$ salt sample was $8.57 \%$ and refrigerated and frozen meatball of $3.0 \%$ salt sample at 21 and 60 days were $8.52 \%$ and $8.28 \%$, respectively. Fat of fresh meatball of $5.0 \%$ salt sample was $8.55 \%$ and refrigerated and frozen meatball of $5.0 \%$ salt sample at 21 and 60 days were $8.44 \% 8.26 \%$, respectively. Fat value of meatball decreased with advanced of storage time, temperature and salt concentration. This result is well matched with the findings of Huda et al. (2010) where the authors found that the Malayasian commercial beef meatball ranged from 7.05\%-9.25\% crude fat.

\section{$p H$}

$\mathrm{pH}$ value of samples was also analyzed up to the end of the storage period of 60 days and the results are presented in Table 1. $\mathrm{pH}$ of fresh meatball of $0 \%$ salt sample was 5.68, refrigerated sausage and frozen meatball of $0 \%$ salt sample at 21 days and 60 days were 5.75 and 4.11, respectively. $\mathrm{pH}$ of fresh meatball of $1.5 \%$ salt sample was 4.79 and refrigerated and frozen meatball of $1.5 \%$ salt sample at 21 and 60 days were 4.51 and 4.09, respectively. $\mathrm{pH}$ of fresh beef meatball of $3.0 \%$ salt sample was 4.86 and refrigerated and frozen meatball of $3.0 \%$ salt sample at 21 and 60 days were 4.65 and 4.10 , respectively. $\mathrm{pH}$ of fresh meatball of $5.0 \%$ salt sample was 4.81 and refrigerated and frozen meatball of $5.0 \%$ salt sample at 21 and 60 days were 4.98 and 4.03, respectively. $\mathrm{pH}$ value of meatball decreased with advanced of storage time, temperature and salt concentration.

\section{Cooking loss}

Cooking loss of samples was also analyzed up to the end of the storage period of 60 days and the results are presented in Table 1 . Cooking loss of fresh meatball of $0 \%$ salt sample was $25.67 \%$, refrigerated and frozen meatball of $0 \%$ salt sample at 21 days and 60 days were $20.63 \%$ and $27.11 \%$, respectively. Cooking loss of fresh meatball of $1.5 \%$ salt sample was $27.19 \%$ and refrigerated and frozen meatball of $1.5 \%$ salt sample at 21 and 60 days were $23.35 \%$ and $26.66 \%$, respectively. Cooking loss of fresh meatball of $3.0 \%$ salt sample was $27.17 \%$ and refrigerated and frozen meatball of $3.0 \%$ salt sample at 21 and 60 days were $23.12 \%$ and $26.18 \%$, respectively. Cooking loss of fresh meatball of $5.0 \%$ salt sample was $27.16 \%$ and refrigerated and frozen meatball of $5.0 \%$ salt samples at 21 and 60 days were $28.04 \%$ and $25.10 \%$, respectively. Cooking loss of meatball increased with advanced of salt concentration but decreased with advanced of storage time and temperature. 
Table 1. Proximate composition of meatball

\begin{tabular}{|c|c|c|c|c|c|c|c|c|c|}
\hline \multirow[t]{2}{*}{ Treatment } & \multirow[t]{2}{*}{ Parameters } & \multirow{2}{*}{$\begin{array}{c}\begin{array}{c}\text { Fresh } \\
\text { sample }\end{array} \\
0 \text { Days }\end{array}$} & \multicolumn{3}{|c|}{ Refrigerated sample } & \multicolumn{4}{|c|}{ Frozen sample } \\
\hline & & & 7 Days & 14 Days & 21 Days & 15 Days & 30 Days & 45 Days & 60 Days \\
\hline \multirow[t]{6}{*}{$\mathrm{T}_{1}$} & $\mathrm{DM} \%$ & 31.57 & 31.63 & 32 & 33.59 & 31.78 & 31.86 & 32.33 & 32.54 \\
\hline & Ash \% & 1.14 & 1.10 & 1.05 & 1.03 & 1.16 & 1.12 & 1.11 & 1.14 \\
\hline & $\mathrm{CP} \%$ & 22.31 & 21.63 & 21.48 & 21.44 & 19.52 & 18.85 & 18.13 & 23.08 \\
\hline & Fat $\%$ & 8.90 & 8.66 & 8.79 & 8.80 & 8.62 & 8.62 & 8.55 & 8.43 \\
\hline & $\mathrm{pH}$ & 5.68 & 5.71 & 5.68 & 5.75 & 4.25 & 4.22 & 4.12 & 4.11 \\
\hline & CL\% & 25.67 & 22.63 & 21.02 & 20.63 & 28.27 & 27.77 & 27.12 & 27.11 \\
\hline \multirow[t]{6}{*}{$\mathrm{T}_{2}$} & DM\% & 31.46 & 31.64 & 32.40 & 33.57 & 31.93 & 31.94 & 32.49 & 34.25 \\
\hline & Ash $\%$ & 1.16 & 1.14 & 1.08 & 1.04 & 1.13 & 1.12 & 1.07 & 1.13 \\
\hline & СР\% & 20.55 & 21.30 & 20.24 & 20.47 & 19.64 & 18.94 & 18.21 & 21.53 \\
\hline & Fat $\%$ & 8.58 & 8.59 & 8.53 & 8.51 & 8.50 & 8.52 & 8.48 & 8.27 \\
\hline & $\mathrm{pH}$ & 4.79 & 4.76 & 4.55 & 4.51 & 4.18 & 4.16 & 4.09 & 4.09 \\
\hline & CL\% & 27.19 & 25.35 & 25.53 & 23.35 & 27.19 & 27.00 & 27.02 & 26.66 \\
\hline \multirow[t]{6}{*}{$\mathrm{T}_{3}$} & DM\% & 31.65 & 31.72 & 31.97 & 33.43 & 32.42 & 33.51 & 33.55 & 33.76 \\
\hline & Ash\% & 1.18 & 1.11 & 1.08 & 1.07 & 1.05 & 1.05 & 1.07 & 1.11 \\
\hline & $\mathrm{CP} \%$ & 14.55 & 21.11 & 20.62 & 20.45 & 19.87 & 19.21 & 19.02 & 21.48 \\
\hline & Fat $\%$ & 8.57 & 8.48 & 8.54 & 8.52 & 8.44 & 8.56 & 8.53 & 8.28 \\
\hline & $\mathrm{pH}$ & 4.86 & 4.71 & 4.71 & 4.65 & 4.18 & 4.15 & 4.09 & 4.10 \\
\hline & CL\% & 27.17 & 27.00 & 25.49 & 23.12 & 26.62 & 26.64 & 26.32 & 26.18 \\
\hline \multirow[t]{6}{*}{$\mathrm{T}_{4}$} & DM\% & 31.84 & 31.47 & 32.52 & 33.44 & 33.75 & 33.87 & 33.86 & 33.83 \\
\hline & Ash\% & 1.17 & 1.14 & 1.03 & 1.04 & 1.10 & 1.08 & 1.06 & 1.07 \\
\hline & $\mathrm{CP} \%$ & 20.13 & 20.95 & 23.33 & 20.37 & 20.01 & 19.59 & 19.50 & 21.37 \\
\hline & Fat $\%$ & 8.55 & 8.52 & 8.49 & 8.44 & 8.36 & 8.52 & 8.41 & 8.26 \\
\hline & $\mathrm{pH}$ & 4.81 & 4.75 & 5.52 & 4.98 & 4.05 & 4.05 & 4.04 & 4.03 \\
\hline & CL\% & 27.16 & 27.06 & 26.64 & 28.04 & 23.63 & 28.75 & 28.66 & 25.10 \\
\hline
\end{tabular}

$\mathrm{T}_{1}=0 \%$ salt; $\mathrm{T}_{2}=1.5 \%$ salt concentration; $\mathrm{T}_{3}=3 \%$ salt concentration; $\mathrm{T}_{4}=5 \%$ salt concentration and $\mathrm{CL}$ $=$ Cooking loss

\section{Sensory evaluation}

Table 2 shows the result of sensory evaluation of beef meatball. Fresh meatball samples were analyzed for their color, tenderness, juiciness, flavor, texture, coarseness, hardness, saltiness taste and overall impression by 5 panelists familiar with meatball evaluation. Panelists were selected among teachers. Sensory evaluation was carried out in individual boothsunder controlled conditions of light, temperature, and humidity. Prior to sample evaluation, all panelists participated in orientation sessions to familiarize with the scale attributes (off-odor, freshness, overall, and so on) of fresh meatball using an intensity scale. Sensory qualities of the samples were evaluated using a 5-point scoring method. Sensory scores were 5 for excellent, 4 for very good, 3 for good, 2 for fair, and 1 for poor. All samples were served in the petri dishes and were returned for further chemical analysis. Sensory evaluation was accomplished at day 0 . 


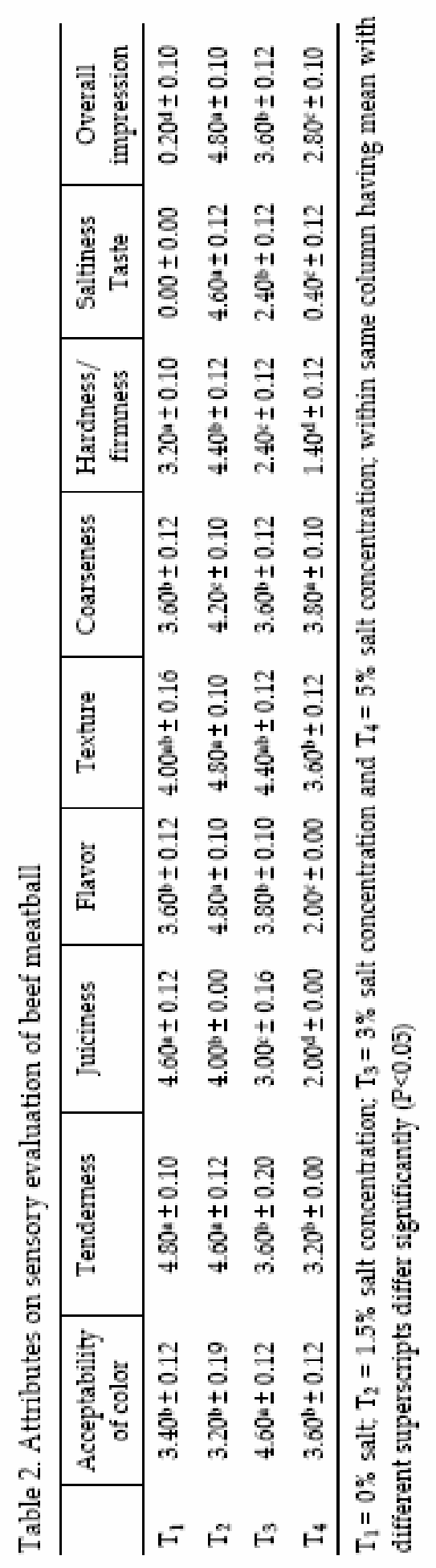




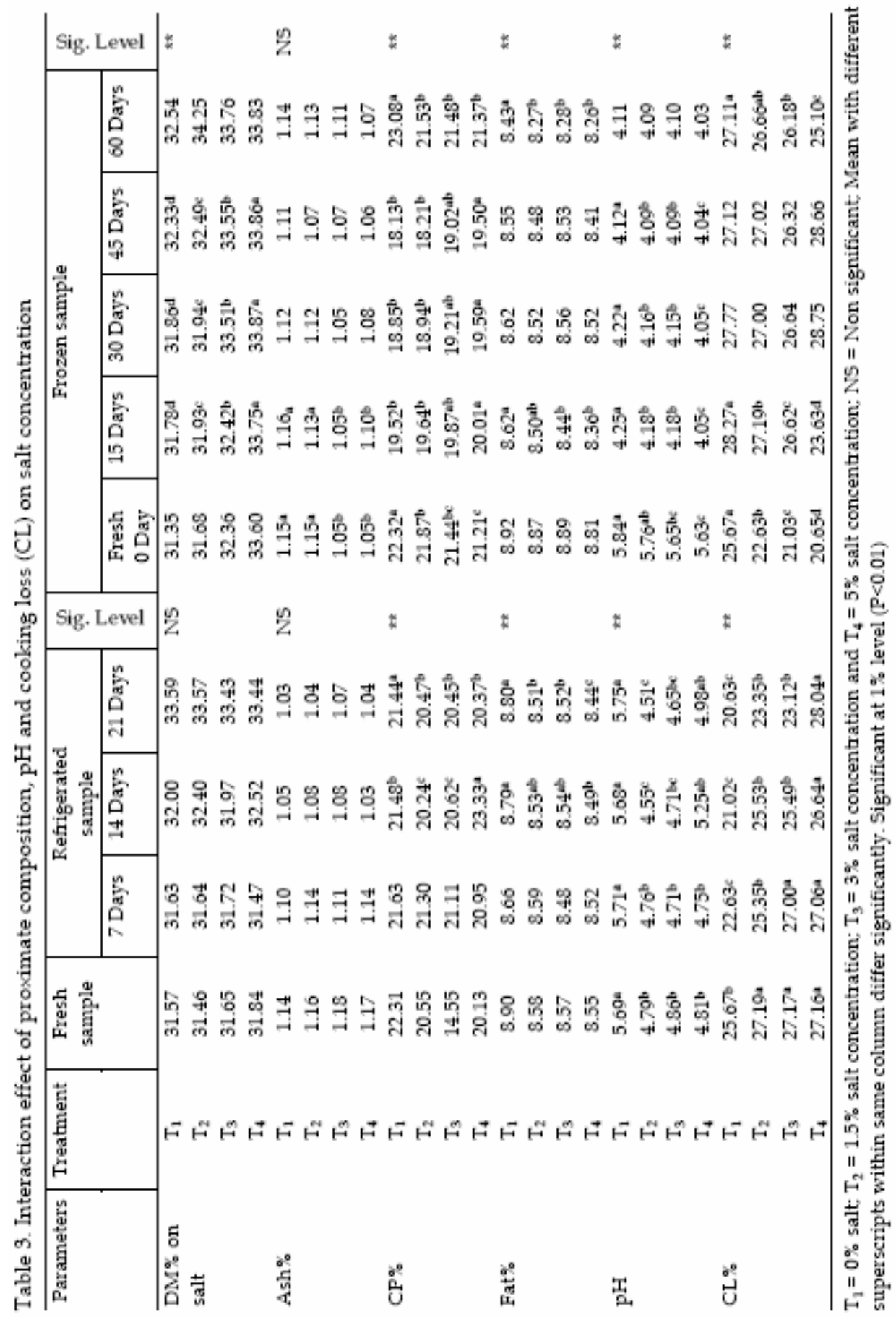


Table 4. Interaction effect of proximate composition, $\mathrm{pH}$ and cooking loss (CL) of fresh and refrigerated sausage on storage time

\begin{tabular}{|c|c|c|c|c|c|c|}
\hline \multirow[t]{2}{*}{ Parameters } & \multirow{2}{*}{$\begin{array}{c}\text { Duration } \\
\text { (days) }\end{array}$} & \multirow[t]{2}{*}{$\mathrm{T}_{1}$} & \multicolumn{3}{|c|}{ Treatment } & \multirow{2}{*}{$\begin{array}{l}\text { Sig. } \\
\text { Level }\end{array}$} \\
\hline & & & $\mathrm{T}_{2}$ & $\mathrm{~T}_{3}$ & $\mathrm{~T}_{4}$ & \\
\hline \multirow[t]{4}{*}{ DM \% } & 0 & $31.57 \mathrm{c}$ & $31.46^{c}$ & $31.65^{b}$ & $31.84^{c}$ & $* *$ \\
\hline & 7 & $31.63^{c}$ & $31.64^{c}$ & $31.72^{b}$ & $31.47 \mathrm{c}$ & \\
\hline & 14 & $32.00^{b}$ & $32.40^{\mathrm{b}}$ & 31.97ab & $32.52^{b}$ & \\
\hline & 21 & $33.59 a$ & $33.57 \mathrm{a}$ & $33.43^{a}$ & $33.44^{\mathrm{a}}$ & \\
\hline \multirow[t]{4}{*}{ Ash $\%$} & 0 & $1.14^{\mathrm{a}}$ & $1.16^{\mathrm{a}}$ & $1.18^{\mathrm{a}}$ & $1.17 \mathrm{a}$ & $* *$ \\
\hline & 7 & $1.10^{\mathrm{b}}$ & $1.14^{\mathrm{b}}$ & $1.11^{b}$ & $1.14^{\mathrm{b}}$ & \\
\hline & 14 & $1.05^{c}$ & $1.08^{c}$ & $1.08^{c}$ & $1.03^{c}$ & \\
\hline & 21 & $1.03^{c}$ & $1.04^{\mathrm{c}}$ & $1.07 \mathrm{c}$ & $1.04^{\mathrm{c}}$ & \\
\hline \multirow[t]{4}{*}{$\mathrm{CP} \%$} & 0 & 22.31 & $20.55^{b}$ & 14.55 & $20.13^{b}$ & $* *$ \\
\hline & 7 & 21.63 & $21.30^{\mathrm{a}}$ & 21.11 & $20.95^{\mathrm{ab}}$ & \\
\hline & 14 & 21.48 & $20.24^{c}$ & 20.62 & $23.33^{a}$ & \\
\hline & 21 & 21.44 & $20.47^{b}$ & 20.45 & $20.37 \mathrm{~b}$ & \\
\hline \multirow[t]{4}{*}{ Fat $\%$} & 0 & $8.90^{\mathrm{a}}$ & $8.58^{\mathrm{b}}$ & 8.57 & 8.55 & $* *$ \\
\hline & 7 & $8.66^{c}$ & $8.59^{a}$ & 8.48 & 8.52 & \\
\hline & 14 & $8.79 \mathrm{~b}$ & $8.53^{c}$ & 8.54 & 8.49 & \\
\hline & 21 & $8.80^{\mathrm{b}}$ & $8.51^{\mathrm{c}}$ & 8.52 & 8.44 & \\
\hline \multirow[t]{4}{*}{$\mathrm{pH}$} & 0 & $5.69 \mathrm{ab}$ & $4.79 \mathrm{a}$ & $4.86^{\mathrm{a}}$ & $4.81^{b}$ & $* *$ \\
\hline & 7 & $5.71^{\mathrm{ab}}$ & $4.76^{\mathrm{a}}$ & $4.71^{\mathrm{ab}}$ & $4.75^{\mathrm{b}}$ & \\
\hline & 14 & $5.68^{\mathrm{b}}$ & $4.55^{\mathrm{b}}$ & $4.71^{\mathrm{ab}}$ & $5.25^{\mathrm{a}}$ & \\
\hline & 21 & $5.75^{\mathrm{a}}$ & $4.51^{\mathrm{b}}$ & $4.65^{\mathrm{b}}$ & $4.98^{\mathrm{ab}}$ & \\
\hline \multirow[t]{4}{*}{ CL\% } & 0 & $25.67 \mathrm{a}$ & $27.19^{a}$ & $27.17 \mathrm{a}$ & $27.16^{\mathrm{b}}$ & $* *$ \\
\hline & 7 & $22.63^{b}$ & $25.35^{b}$ & $27.00^{\mathrm{ab}}$ & $27.06^{\mathrm{bc}}$ & \\
\hline & 14 & $21.02^{c}$ & $25.53^{\mathrm{ab}}$ & $25.49 \mathrm{~b}$ & $26.64^{c}$ & \\
\hline & 21 & $20.63^{d}$ & $23.35^{c}$ & $23.12^{c}$ & $28.04^{\mathrm{a}}$ & \\
\hline
\end{tabular}

$\mathrm{T}_{1}=0 \%$ salt; $\mathrm{T}_{2}=1.5 \%$ salt concentration; $\mathrm{T}_{3}=3 \%$ salt concentration and $\mathrm{T}_{4}=5 \%$ salt concentration; Mean with different superscripts within same column differ significantly; Significant at $1 \%$ level $(\mathrm{P}<0.01)$

\section{Interaction effects}

Interaction effects of proximate composition, $\mathrm{pH}$ and cooking loss of meatball on storage time and salt concentration was shown in Table 3, 4 and 5. There were little changes of dry matter content during storage time. DM content increased with the increase of storage time and salt concentration in all samples and differed significantly $(\mathrm{P}<0.01)$ among the parameters. Ash value increased with the increase of storage time salt concentration in all samples and differed significantly $(\mathrm{P}<0.01)$ among the parameters. The $\mathrm{CP}$ content decreased due to loss of protein during storage time in those samples might be related with the loss of sarcoplasmic protein, osmosis and poor water holding capacity and differed significantly $(\mathrm{P}<0.01)$ among the parameters. Fat value of meatball decreased with the advances of storage time, temperature and salt concentration and differed significantly $(\mathrm{P}<0.01)$ among the parameters. $\mathrm{pH}$ value of beef meatball decreased with the advances of storage time and decreased with the increase of temperature and salt concentration and 
differed significantly $(\mathrm{P}<0.01)$ among the parameters. Cooking loss of beef meatball decreased with the advances of salt concentration but increased with the advances of storage time and temperature and differed significantly $(\mathrm{P}<0.01)$ among the parameters.

Table 5. Interaction effect of proximate composition, $\mathrm{pH}$ and cooking loss (CL) of fresh and frozen sausage on storage time

\begin{tabular}{|c|c|c|c|c|c|c|}
\hline \multirow[t]{2}{*}{ Parameters } & \multirow{2}{*}{$\begin{array}{l}\text { Storage time } \\
\text { (Days) }\end{array}$} & \multicolumn{4}{|c|}{ Treatment } & \multirow[t]{2}{*}{ Sig. Level } \\
\hline & & $\mathrm{T}_{1}$ & $\mathrm{~T}_{2}$ & $\mathrm{~T}_{3}$ & $\mathrm{~T}_{4}$ & \\
\hline \multirow{5}{*}{$\begin{array}{l}\mathrm{DM} \% \text { on } \\
\text { storage time }\end{array}$} & 0 & $31.35^{\mathrm{d}}$ & 31.68 & 32.36 & $33.60^{c}$ & ** \\
\hline & 15 & $31.78 \mathrm{c}$ & 31.93 & 32.42 & $33.75^{b}$ & \\
\hline & 30 & $31.86^{c}$ & 31.94 & 33.51 & $33.87 \mathrm{a}$ & \\
\hline & 45 & $32.33^{b}$ & 32.49 & 33.55 & $33.86^{\mathrm{a}}$ & \\
\hline & 60 & $32.54^{\mathrm{a}}$ & 34.25 & 33.76 & $33.83^{\mathrm{ab}}$ & \\
\hline \multirow[t]{5}{*}{ Ash\% } & 0 & 1.15 & 1.15 & 1.05 & 1.05 & NS \\
\hline & 15 & 1.16 & 1.13 & 1.05 & 1.10 & \\
\hline & 30 & 1.12 & 1.12 & 1.05 & 1.08 & \\
\hline & 45 & 1.11 & 1.07 & 1.07 & 1.06 & \\
\hline & 60 & 1.14 & 1.13 & 1.11 & 1.07 & \\
\hline \multirow[t]{5}{*}{$\mathrm{CP} \%$} & 0 & $22.32^{b}$ & $21.87 a$ & $21.44^{\mathrm{a}}$ & $21.21^{\mathrm{a}}$ & $* *$ \\
\hline & 15 & $19.52^{c}$ & $19.64^{c}$ & $19.87 \mathrm{~b}$ & $20.01^{b}$ & \\
\hline & 30 & $18.85^{\mathrm{d}}$ & $18.94^{\mathrm{d}}$ & $19.21^{\mathrm{c}}$ & $19.59 c$ & \\
\hline & 45 & 18.13 e & $18.21 \mathrm{e}$ & $19.02^{d}$ & $19.50 c$ & \\
\hline & 60 & $23.08^{a}$ & $21.53^{b}$ & $21.48^{\mathrm{a}}$ & $21.37 \mathrm{a}$ & \\
\hline \multirow[t]{5}{*}{ Fat $\%$} & 0 & $8.92^{\mathrm{a}}$ & $8.87 \mathrm{a}$ & $8.89 a$ & $8.81^{\mathrm{a}}$ & $* *$ \\
\hline & 15 & $8.62^{b}$ & $8.50^{\mathrm{b}}$ & $8.44^{c}$ & $8.36^{c}$ & \\
\hline & 30 & $8.62^{b}$ & $8.52^{b}$ & $8.56^{b}$ & $8.52^{b}$ & \\
\hline & 45 & $8.55^{b}$ & $8.48^{\mathrm{b}}$ & $8.53^{b}$ & $8.41 b^{c}$ & \\
\hline & 60 & $8.43^{c}$ & $8.27 \mathrm{c}$ & $8.28^{\mathrm{d}}$ & $8.26^{c}$ & \\
\hline \multirow[t]{5}{*}{$\mathrm{pH}$} & 0 & $5.84^{\mathrm{a}}$ & $5.76^{\mathrm{a}}$ & $5.65^{a}$ & $5.63^{a}$ & $* *$ \\
\hline & 15 & $4.25^{\mathrm{b}}$ & $4.18^{\mathrm{b}}$ & $4.18^{\mathrm{b}}$ & $4.05^{b}$ & \\
\hline & 30 & $4.22^{b c}$ & $4.16 b^{c}$ & $4.15^{\mathrm{b}}$ & $4.05^{b}$ & \\
\hline & 45 & $4.12^{\mathrm{cd}}$ & $4.09 c$ & $4.09 \mathrm{~b}$ & $4.04^{b}$ & \\
\hline & 60 & $4.11^{\mathrm{d}}$ & $4.09 c$ & $4.10^{\mathrm{b}}$ & $4.03^{b}$ & \\
\hline \multirow[t]{5}{*}{ CL\% } & 0 & $25.67 \mathrm{~d}$ & $22.63^{d}$ & $21.03^{d}$ & $20.65^{d}$ & ** \\
\hline & 15 & $28.27 \mathrm{a}$ & $27.19 a$ & $26.62^{a}$ & $23.63 c$ & \\
\hline & 30 & $27.77 \mathrm{~b}$ & $27.00^{\mathrm{b}}$ & $26.64^{a}$ & $28.75^{\mathrm{a}}$ & \\
\hline & 45 & $27.12^{c}$ & $27.02^{b}$ & $26.32^{b}$ & $28.66^{\mathrm{ab}}$ & \\
\hline & 60 & $27.11^{c}$ & $26.66^{c}$ & $26.18^{c}$ & $25.10^{\mathrm{b}}$ & \\
\hline
\end{tabular}

$\mathrm{T}_{1}=0 \%$ salt; $\mathrm{T}_{2}=1.5 \%$ salt concentration; $\mathrm{T}_{3}=3 \%$ salt concentration and $\mathrm{T}_{4}=5 \%$ salt concentration; $\mathrm{NS}$

= Non significant; Mean with different superscripts within same column differ significantly; Significant at $1 \%$ level $(\mathrm{P}<0.01)$ 


\section{REFERENCES}

AOAC. 1995. Official Methods of Analysis, $16^{\text {th }}$ ed. Washington: Association Official Analytical Chemistry.

Asghar, A., Gray, J. I., Buckley, D. J., Pearson, A. M. and Booren, A. M. 1988. Perspectives on warmedover flavor. Food Technology, 42: 102-108.

Bangladesh Economic Review (BER) 2009. Ministry of Finance, Economic Advisory Division, Ministry of Finance, Government of Bangladesh. June, 2009.

Chantrapornchai, W. and McClements, D. J. 2002. Influence of $\mathrm{NaCl}$ on optical properties, large-strain rheology and water holding capacity of heat-induced whey protein isolate gels. Food Hydrocolloids, 16: 467-476.

DLS, 2009. Personal communication, Directorate of livestock Services, Ministry of Livestock and Fisheries, Dhaka.

Durack, E., Alonso-Gomez, M. and Wilkinson, M. G. 2008. Salt: a review of its role in food science and public health. Current Nutrition \& Food Science, 4: 290-297.

Foegeding, E. A. and Lanier, T. C. 1987. The contribution of nonmuscle proteins to texture of gelled muscle protein foods. Cereal Foods World, 32: 202-205.

Fennema, O. R. 1975. Introduction to food preservation. In: principles of Food Science. (Ed. O. R. Fennema). Marcel Dekker, Inc. New York. pp. 1-7.

Hsu, S. Y., and Yu, S. H. 1999. Effects of phosphate, water, fat, and salt on qualities of low-fat emulsified meatball. Journal of Food Engineering, 39: 123-130.

Huda, N., Shen, Y. H., Huey, Y. L., Ahmad, R. and Mardiah, A. 2010. Evaluation of physico-chemical properties of Malaysian commercial beef meatbal. Am. J. Food Technol., 5(1): 13-21.

Tobin, B., O'Sullivan, M. G., Hamill, R. and Kerry, J. P. 2012a. Effect of varying salt and fat levels on the sensory quality of beef patties. Meat Science, 91: 460-465.

Tobin, B., O'Sullivan, M. G., Hamill, R. and Kerry, J. P. 2012b. Effect of varying salt and fat levels on the sensory and physiochemical quality of frankfurters. Meat Science (Submitted). 